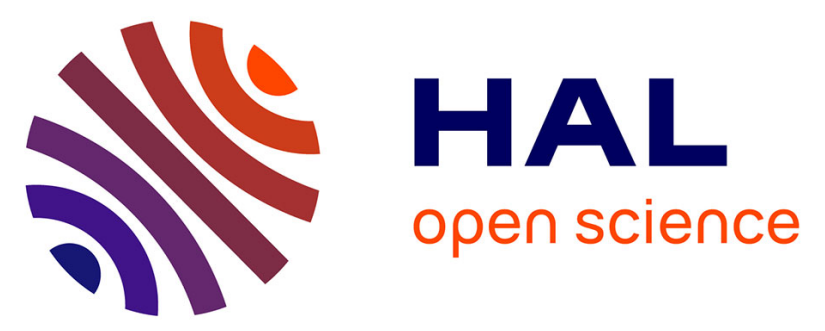

\title{
Azine and Diazine Functionalization Using 2,2,6,6-Tetramethylpiperidino-Based Lithium-Metal Combinations: Application to the Synthesis of 5,9-Disubstituted Pyrido[3',2':4,5]pyrrolo[1,2-c] pyrimidines
}

Nada Marquise, Tan Tai Nguyen, Floris Chevallier, Laurent Picot, Valérie Thiéry, Olivier Lozach, Stéphane Bach, Sandrine Ruchaud, Florence Mongin

\section{- To cite this version:}

Nada Marquise, Tan Tai Nguyen, Floris Chevallier, Laurent Picot, Valérie Thiéry, et al.. Azine and Diazine Functionalization Using 2,2,6,6-Tetramethylpiperidino-Based Lithium-Metal Combinations: Application to the Synthesis of 5,9-Disubstituted Pyrido[3',2':4,5]pyrrolo[1,2-c] pyrimidines. SYNLETT, 2015, 26 (20), pp.2811-2816. 10.1055/s-0035-1560496 . hal-01248092

\section{HAL Id: hal-01248092}

\section{https://hal-univ-rennes1.archives-ouvertes.fr/hal-01248092}

Submitted on 4 Jan 2016

HAL is a multi-disciplinary open access archive for the deposit and dissemination of scientific research documents, whether they are published or not. The documents may come from teaching and research institutions in France or abroad, or from public or private research centers.
L'archive ouverte pluridisciplinaire HAL, est destinée au dépôt et à la diffusion de documents scientifiques de niveau recherche, publiés ou non, émanant des établissements d'enseignement et de recherche français ou étrangers, des laboratoires publics ou privés. 


\section{Azine and Diazine Functionalization Using 2,2,6,6-Tetrameth- ylpiperidino-Based Lithium-Metal Combinations: Application to the Synthesis of 5,9-Disubstituted Pyrido[3',2':4,5]pyrrolo[1,2-c] pyrimidines}

\author{
Nada Marquise \\ Tan Tai Nguyen ${ }^{\mathrm{a}}$ \\ Floris Chevallier ${ }^{\mathrm{a}}$ \\ Laurent Picot ${ }^{\mathrm{b}}$ \\ Valérie Thiéry*b \\ Olivier Lozachc \\ Stéphane Bach*c \\ Sandrine Ruchaud ${ }^{c}$ \\ Florence Mongin *a
}

a Equipe Chimie et Photonique Moléculaires, Institut des Sciences Chimiques de Rennes, UMR 6226, CNRS-Université de Rennes 1 , Bâtiment 10A, Case 1003, Campus de Beaulieu, 35042 Rennes, France

florence.mongin@univ-rennes1.fr

b Laboratoire Littoral Environnement et Sociétés, UMRi CNRS 7266 ,

Université de La Rochelle, 17042 La Rochelle, France

valerie.thiery@univ-Ir.fr

c USR 3151, CNRS-Université Pierre et Marie Curie, Kinase Inhibitor

Specialized Screening Facility, KISSf, Station Biologique, 29680

Roscoff, France

bach@sb-roscoff.fr
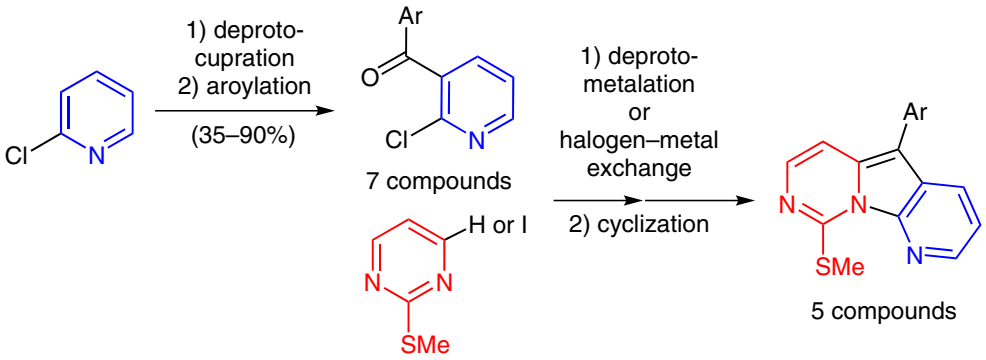

5 compounds

\section{Received: 09.07.2015}

Accepted after revision: 18.09.2015

Published online: 30.09 .2015

DOI: 10.1055/s-0035-1560496; Art ID: st-2015-s0524-c

Abstract The synthesis of triaryl methanols was investigated by reacting different 4-metalated 2-substituted pyrimidines with diaryl ketones, the latter being generated by deprotocupration-aroylation of azine and diazine substrates. Cyclization of the triaryl methanols thus obtained afforded pyrido[3',2':4,5]pyrrolo[1,2-c]pyrimidines, which were evaluated for kinase inhibition and antiproliferative activities in melanoma cells.

Key words diaryl ketone, pyrimidine, deprotometalation, mixed-metal amide, variolin analogue

Variolins are a family of marine alkaloids isolated from the Antartic sponge Kirkpatrickia varialosa. ${ }^{1}$ Among them, variolin $B$ is a tricyclic system bearing a substituent at the 5-position endowed with biological properties such as antitumor and antiviral. ${ }^{1 \mathrm{a}, 2}$ Several total syntheses of variolin $\mathrm{B}$ and analogues have been reported. ${ }^{2 \mathrm{~b}, 3}$ In the convergent synthesis of Morris, ${ }^{3 b, 3 h, 4}$ the key step involves the tandem deoxygenation-cyclization of a triaryl methanol, the latter being for example obtained by reaction of 2-chloro-3lithio-4-methoxypyridine on a symmetrical ketone (Scheme 1).<smiles>COc1ccnc(Cl)c1Cl</smiles><smiles></smiles><smiles>Nc1nccc(-c2c3c(O)ccnc3n3c(N)nccc23)n1</smiles>

Scheme 1 Morris synthesis of variolin B

Because of our interest in the synthesis of diaryl ketones by deprotocupration-aroylation, ${ }^{5}$ we decided to evaluate the reactivity of these ketones toward different 4-metalated 2-substituted pyrimidines in order to reach different triaryl methanols. Thus, the required diaryl ketones were prepared from azines or diazines as reported previously. ${ }^{5}$ The latter were deprotocuprated at room temperature in tetrahydrofuran (THF) containing $N, N, N^{\prime}, N^{\prime}$-tetramethylethylenediamine (TMEDA) by using (TMP) ${ }_{2} \mathrm{CuLi} \cdot \mathrm{LiCl}$ (TMP = 2,2,6,6-tet- 
ramethylpiperidino), prepared in situ from $\mathrm{CuCl}$ and LiTMP (2 equiv). Trapping with aroyl chlorides after two hours furnished the compounds 1a-i (Scheme 2).<smiles>[R]c1[X]c([R])nc([R])c1</smiles><smiles>O=C(c1ccccc1)c1cccnc1Cl</smiles>

1a: $90 \%$<smiles>O=C(c1ccc(C(F)(F)F)cc1)c1cccnc1Cl</smiles><smiles>O=C(c1ccc(Cl)nc1)c1cccnc1Cl</smiles>

1g: $35 \%$

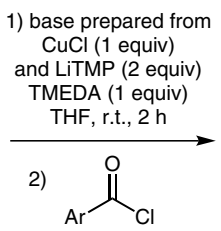<smiles>[R]c1nc([R])c(C(=O)[Te])c([R])n1</smiles><smiles>O=C(c1ccccc1)c1ccc(Cl)nc1Cl</smiles><smiles>O=C(c1ccc(Cl)cc1)c1cccnc1Cl</smiles><smiles>COc1ccc(C(=O)c2cccnc2Cl)cc1</smiles><smiles>O=C(c1cccnc1Cl)c1cccnc1Cl</smiles><smiles>O=C(c1ccccc1)c1c(Cl)ncnc1Cl</smiles>
1h: $21 \%$<smiles>COc1ncc(C(=O)c2ccccc2Cl)c(OC)n1</smiles>

1i: $58 \%$
Scheme 2 Synthesis of the diaryl ketones $\mathbf{1 a - i}$

We next considered the formation of 4-metalated 2-chloropyrimidine from 2 and its trapping. The pyrimidine 2 being prone to nucleophilic attacks, ${ }^{6}$ we first tried to use the base prepared in situ by mixing $\mathrm{ZnCl}_{2}$.TMEDA and LiTMP in a $1: 3$ ratio, $^{7}$ and supposed to be a $1: 1$ LiTMP.2LiCl( \pm TMEDA)-Zn(TMP $)_{2}$ mixture. ${ }^{8}$ It proved not appropriate, with the iodide $4 a$ isolated in a low $18 \%$ yield when the deprotonation step was performed at $0{ }^{\circ} \mathrm{C}$ and only degradation noticed at higher temperatures. TMPMgCl. $\mathrm{LiCl}$ being a suitable base for 2 in THF at $-60{ }^{\circ} \mathrm{C}$, as evidenced by subsequent iodolysis after two hours, ${ }^{9}$ we thus employed it in order to attempt the interception of the deprotomagnesated species with the ketone 1a. The expected triaryl methanol $\mathbf{4 b}$ was obtained in a moderate $33 \%$ yield by carrying out the reaction at $-60{ }^{\circ} \mathrm{C}$, but its formation could be improved with a deprotonation step at $-40{ }^{\circ} \mathrm{C}$ (Scheme 3).

4-Metalated derivatives of 2-(methylthio)pyrimidine (3) could be formed at room temperature in THF by using either the previous lithium-zinc base or the corresponding lithium-cadmium base, prepared in situ by mixing $\mathrm{CdCl}_{2}$.TMEDA ( 0.5 equiv) and LiTMP ( 1.5 equiv). ${ }^{10}$ This was evidenced by iodolysis to afford $\mathbf{5 a}$ in correct yields. When $\mathrm{TMPMgCl} \cdot \mathrm{LiCl}$ was employed at $-60{ }^{\circ} \mathrm{C}$, the alcohol $\mathbf{5 b}$ resulting from a quenching with the ketone 1a was obtained in a moderate $21 \%$ yield (Scheme 4 ).

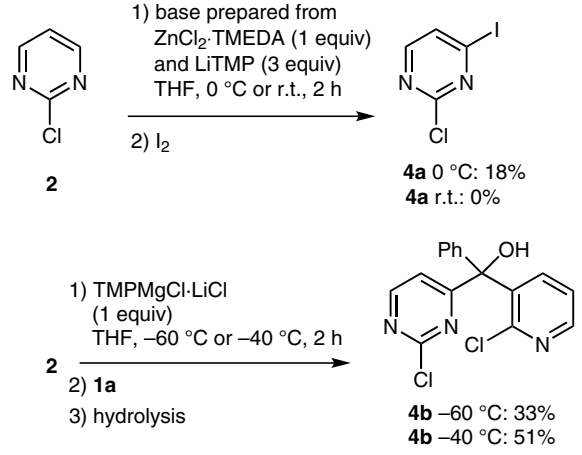

Scheme 3 Functionalization of 2-chloropyrimidine (2)

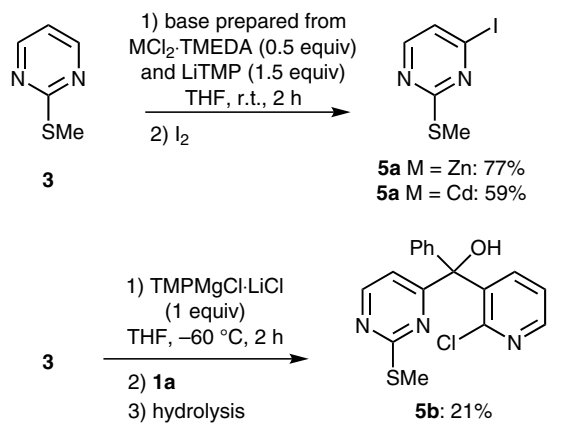

Scheme 4 Functionalization of 2-(methylthio)pyrimidine (3)

To reach the triaryl methanols, it also proved possible to involve the iodide 5a in a butyllithium-mediated halogenmetal exchange reaction in the presence of the ketone 1a or 1b. Performing this reaction in $\mathrm{THF}$ at $-95^{\circ} \mathrm{C}$, as previously documented by Morris, ${ }^{3 \mathrm{~b}, \mathrm{~h}, 4}$ led to the alcohol $\mathbf{5 b}$ or $\mathbf{6 b}$ in $72 \%$ or $45 \%$ yield, respectively. Replacing methanol quenching with acetyl chloride afforded the corresponding acetate $\mathbf{5 b}$ '. Finally, treating both $\mathbf{5 b}$ and $\mathbf{5} \mathbf{b}^{\prime}$ with triethylsilane and trifluoroacetic acid at $100{ }^{\circ} \mathrm{C}$ in 1,2 -dichloroethane furnished the phenyl-substituted tricycle $\mathbf{7 b}$ in $45 \%$ yield (Scheme 5). Because no improvement was here noted by using the acetate $\mathbf{5} \mathbf{b}^{\prime}$ as intermediate, ${ }^{4}$ we kept the sequence involving triaryl methanols for the rest of the study.

In order to prepare analogues of 9-(methylthio)-5phenylpyrido[3',2';4,5]pyrrolo[1,2-c]pyrimidine (7b), we aimed at synthesizing various triaryl methanols (Table 1). When 2-chloro-4-iodopyrimidine (4a) was involved instead of $5 \mathbf{a}$ in the reaction with 1a, a lower $24 \%$ yield was noticed (Table 1, entries 1 and 2). With the other aryl(2-chloro-3pyridyl)methanones 1c-e, the expected alcohols were isolated in yields ranging from 52-70\% (Table 1, entries 3-5). The position of chlorine on the (2-chloro-3-pyridyl)(chloro3-pyridyl)methanone is an important parameter for the success of the reaction. Indeed, whereas a good $75 \%$ yield was registered by using $\mathbf{1 f}$ (compound 5f, Table 1, entry 6), a complex mixture without the expected derivative togeth- 


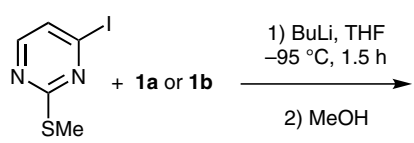

$5 a$

$$
5 a+1 a
$$

$$
\downarrow \begin{gathered}
\text { 1) BuLi, THF } \\
-95^{\circ} \mathrm{C}, 1.5 \mathrm{~h} \\
\text { 2) AcCl }
\end{gathered}
$$<smiles>COC(=O)c1cccnc1C(OC(C)=O)(c1ccccc1)c1ccnc(SC)n1</smiles>

$5 b^{\prime}: 68 \%$

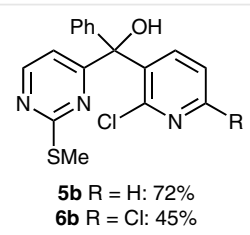

\begin{tabular}{c|}
$\mathrm{Et}_{3} \mathrm{SiH}$ (8 equiv) \\
TFA (2 equiv) \\
DCE \\
$100^{\circ} \mathrm{C}, 48 \mathrm{~h}$
\end{tabular} \mid $\mathrm{R}=\mathrm{H}$<smiles>CSc1nccc2c(-c3ccccc3)c3cccnc3n12</smiles>

7b: $45 \%$
Scheme 5 Synthesis of 9-(methylthio)-5-phenylpyrido[3',2':4,5]pyrrolo[1,2-c]pyrimidine (7b)

er with starting material was obtained from $\mathbf{1 g}$ (Table 1, entry 7). With the ketones $\mathbf{1 h}$ and $\mathbf{1 i}$ bearing a pyrimidyl group, things become difficult, probably in relation with ring sensitivity to nucleophilic attacks; as a consequence, the alcohol $\mathbf{5 i}$ was the only to be formed, in a very low $8 \%$ yield (Table 1, entries 8 and 9).

Table 1 Synthesis of the Triaryl Methanols $\mathbf{4 b}$ and $\mathbf{5 b} \mathbf{b} \mathbf{i}$<smiles>[X]c1nccc(I)n1</smiles>

4a: $\mathrm{X}=\mathrm{Cl}$ 5a: $X=S M e$ Entry 1) BuLi, THF 2) hydrolysis<smiles>[R]C1=C(C(O)(Br)c2ccnc([X])n2)C(Cl)=[Y]C[Z]1</smiles>
$5 b-i$
1 $4 \mathrm{a} \mathrm{Cl}$ 1a

Substrate $\mathrm{X}$

bstrate X

$2 \quad 5 a$ SMe 1a

3 5a SMe 1c
Product $\quad$ Yield (\%)<smiles>OC(c1ccccc1)(c1cccnc1Cl)c1cccnc1Cl</smiles>

$4 \mathrm{~b}$<smiles>CSc1nccc(C(O)(c2ccccc2)c2cccnc2Cl)n1</smiles><smiles>CSc1nccc(C(O)(c2ccc(Cl)cc2)c2cccnc2Cl)n1</smiles>

6 5a SMe $1 f$

5a SMe

$1 \mathrm{~g}$

8 5a SMe

1h

$$
9 \quad 5 a \mathrm{SMe}
$$$$
1 \mathbf{i}
$$<smiles>COc1nccc(C(O)(c2ccc(Cl)nc2)c2cccnc2Cl)n1</smiles>

$5 g$<smiles>OCc1cccnc1Cl</smiles><smiles>CCC(O)(c1ccnc(S[13F])n1)c1cccnc1Cl</smiles>

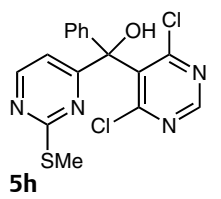

$\mathrm{MeO}$<smiles>[2H]c1ncc(C(O)(c2ccnc(SC)n2)c2cccnc2Cl)c(OC)n1</smiles>

8
$5 i$

In order to progress toward the corresponding 5-aryl tricycles, the triaryl methanols were submitted to the action of triethylsilane and trifluoroacetic acid as before (Table 2 ). Under these conditions, the targets $\mathbf{7 b}$-f $\mathbf{f}$ were generated in moderate yields (Table 2, entries 2-6). No cyclization was noticed from the dichloride $\mathbf{4 b}$ (Table 2, entry 1 ). Similarly, cyclization of the dichloride $\mathbf{6 b}$ did not take place under the conditions used (Table 2, entry 7 ). In both cases, starting material was recovered. 
Table 2 Synthesis of the Tricycles $7 \mathbf{b}-\mathbf{f}$

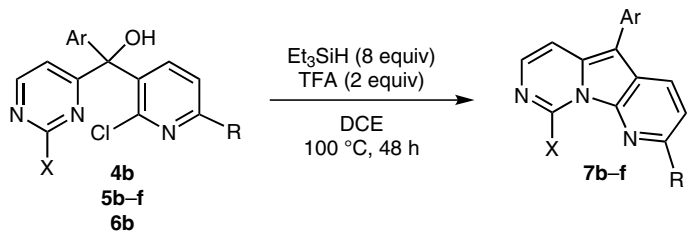

Entry Substrate X, R Product

$35 \mathrm{c} \mathrm{SMe,} \mathrm{H}$<smiles>Cc1nccc2c(-c3ccc(Cl)cc3)c3cccnc3n12</smiles>

$7 c$<smiles>CSc1nccc2c(-c3ccc(C(F)(F)F)cc3)c3cccnc3n12</smiles>

7d<smiles>COc1ccc(-c2c3cccnc3n3c(SC)nccc23)cc1</smiles>

$7 e$<smiles></smiles>

5f SMe, $\mathrm{H}$<smiles>CSc1nccc2c(-c3ccccc3)c3ccc(Cl)nc3n12</smiles>
$0^{\text {a }}$

$7 g$

Variolin B was characterized as a potent inhibitor of cyclin-dependent kinases (CDK), key actors involved notably in the regulation of the cell-division cycle, programmed cell-death by apoptosis, transcription as well as differentiation. ${ }^{2 a}$ This chemical scaffold was consequently used to design new inhibitors of CDK. ${ }^{11}$ In this study we thus tested the new derivatives on a panel of nine protein kinases including CDK5: HsAurora B, HsCDK5/p25, HsRIPK3 (receptor interacting protein kinase), HsHaspin; porcine (Sus scrofa) SsGSK-3 (glycogen synthase kinase-3) and SsCK1 (casein kinase 1); kinases from the protozoan parasites, Leishmania major LmCK1, Plasmodium falciparum PfGSK-3, and from Leishmania donovani LdTLK (tousled-like kinase). These kinases were not significantly affected by the tested chemical compounds (5b-e and $\mathbf{7 c}-\mathbf{f})$ with none of the molecules causing more than $50 \%$ inhibition of enzymatic activity at $10^{-5} \mathrm{M}$.

The antiproliferative activity of the 5,9-disubstituted pyrido[3',2':4,5]pyrrolo[1,2-c]pyrimidines $5 \mathbf{b}-\mathbf{e}$ and $\mathbf{7 c - f}$ was studied in the A2058 (ATCC ${ }^{\circledR}$ CRL-11147) melanoma cell line (Figure 1). A2058 are highly invasive human epithelial adherent melanoma cells, derived from lymph nodes metastatic cells obtained from a 43 years male patient. They are tumorigenic at $100 \%$ frequency in nude mice and considered as very resistant to anticancer drugs.

The compounds 5 exerted low antiproliferative activity in A2058 melanoma cells, with $0-13 \%$ growth inhibition in cells treated for $72 \mathrm{~h}$ at $10^{-5} \mathrm{M}$. In contrast, the compounds 7 exhibited $23-44 \%$ growth inhibition and were considered as moderately antiproliferative. This activity was not correlated to CDK inhibition, as all molecules were inactive at $10^{-5} \mathrm{M}$ in the CDK inhibition assay. Because of the presence of the $\mathrm{sp}^{3}$ carbon, the compounds $\mathbf{5}$ are not planar in contrast to the compounds $\mathbf{7}$. This observation indicates that the planar structure improves the antiproliferative activity and suggests that the cytotoxicity of these new compounds may be related to a DNA intercalating activity, as previously reported with variolin analogues. ${ }^{1 \mathrm{a}, \mathrm{b}}$ The nature of the ring

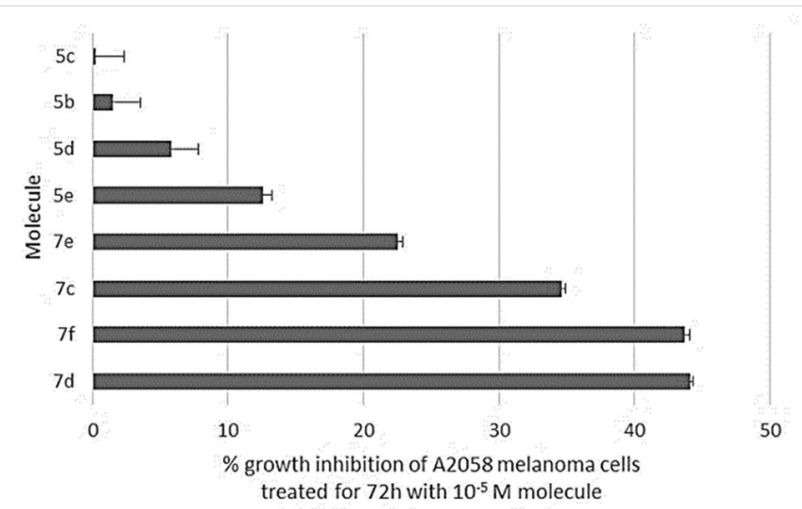

Figure 1 Antiproliferative activity of the compounds $5 \mathbf{b}-\mathbf{e}$ and $\mathbf{7 c}-\mathbf{f}$ in A2058 human melanoma cells grown for $72 \mathrm{~h}$ in a cell-culture medium containing $10^{-5} \mathrm{M}$ molecule 
connected to the tricycle also plays an important role, as the absence of cycle leads to a complete loss of activity, as observed with variolin D. ${ }^{1 c}$ Moreover, the presence of ring nitrogens or/and amino function is also critical for CDK inhibition. $^{2 \mathrm{a}}$

As a conclusion, 2-substituted pyrimidines could be functionalized at their 4-position by using a lithium-metal TMP-based deprotonating agent. ${ }^{12-14}$ The triaryl methanols obtained either after subsequent quenching, or through iodine-lithium exchange with in situ ketone trap, were cyclized to afford new pyrido[3',2':4,5]pyrrolo[1,2-c]pyrimidines.

\section{Acknowledgment}

We gratefully acknowledge financial support from the Institut Universitaire de France (to F.M.), MESR of France (to T.T.N.), Rennes Métropole, and French Cancer League (Comite 17). We also thank the Cancéropôle Grand Ouest (axis: natural sea products in cancer treatment) for scientific support and Biogenouest (Western France life science and environment core facility network) for supporting KISSf screening facility. S.B. is supported by ANR/Investissements d'Avenir program by means of the OCEANOMICs project (grant \# ANR-11BTBR-0008). F.M. thanks Thermo Fisher for generous gift of 2,2,6,6tetramethylpiperidine. We thank Edouard Dean for his contribution to the synthesis experimental work.

\section{Supporting Information}

Supporting information for this article is available online at http://dx.doi.org/10.1055/s-0035-1560496.

\section{References and Notes}

(1) (a) Perry, N. B.; Ettouati, L.; Litaudon, M.; Blunt, J. W.; Munro, M. H. G.; Parkin, S.; Hope, H. Tetrahedron 1994, 50, 3987. (b) Trimurtulu, G.; Faulkner, D. J.; Perry, N. B.; Ettouati, L.; Litaudon, M.; Blunt, J. W.; Munro, M. H. G.; Jameson, G. B. Tetrahedron 1994, 50, 3993. (c) Walker, S. R.; Carter, E. J.; Huff, B. C.; Morris, J. C. Chem. Rev. 2009, 109, 3080.

(2) (a) Simone, M.; Erba, E.; Damia, G.; Vikhanskaya, F.; Di Francesco, A. M.; Riccardi, R.; Bailly, C.; Cuevas, C.; Fernandez SousaFaro, J. M.; D'Incalci, M. Eur. J. Cancer 2005, 41, 2366. (b) Fresneda, P. M.; Delgado, S.; Francesch, A.; Manzanares, I.; Cuevas, C.; Molina, P. J. Med. Chem. 2006, 49, 1217.

(3) (a) Alvarez, M.; Fernandez, D.; Joule, J. A. Tetrahedron Lett. 2001, 42, 315. (b) Anderson, R. J.; Morris, J. C. Tetrahedron Lett. 2001, 42, 8697. (c) Molina, P.; Fresneda, P. M.; Delgado, S.; Bleda, J. A. Tetrahedron Lett. 2002, 43, 1005. (d) Molina, P.; Fresneda, P. M.; Delgado, S. J. Org. Chem. 2003, 68, 489. (e) Ahaidar, A.; Fernandez, D.; Danelon, G.; Cuevas, C.; Manzanares, I.; Albericio, F.; Joule, J. A.; Alvarez, M. J. Org. Chem. 2003, 68, 10020. (f) Ahaidar, A.; Fernandez, D.; Perez, O.; Danelon, G.; Cuevas, C.; Manzanares, I.; Albericio, F.; Joule, J. A.; Alvarez, M. Tetrahedron Lett. 2003, 44, 6191. (g) Mendiola, J.; Baeza, A.; Alvarez-Builla, J.; Vaquero, J. J. J. Org. Chem. 2004, 69, 4974. (h) Anderson, R. J.;
Hill, J. B.; Morris, J. C. J. Org. Chem. 2005, 70, 6204. (i) Baeza, A.; Mendiola, J.; Burgos, C.; Alvarez-Builla, J.; Vaquero, J. J. Tetrahedron Lett. 2008, 49, 4073. (j) Baeza, A.; Mendiola, J.; Burgos, C.; Alvarez-Builla, J.; Vaquero, J. J. Eur. J. Org. Chem. 2010, 5607. (k) Layek, M.; Syam Kumar, Y.; Islam, A.; Karavarapu, R.; Sengupta, A.; Halder, D.; Mukkanti, K.; Pal, M. MedChemComm 2011, 2, 478.

(4) Anderson, R. J.; Morris, J. C. Tetrahedron Lett. 2001, 42, 311.

(5) For a review on the topic, see: Harford, P. J.; Peel, A. J.; Chevallier, F.; Takita, R.; Mongin, F.; Uchiyama, M.; Wheatley, A. E. H. Dalton Trans. 2014, 43, 14181.

(6) See, for example: Wang, X.; Xu, F.; Xu, Q.; Mahmud, H.; Houze, J.; Zhu, L.; Akerman, M.; Tonn, G.; Tang, L.; McMaster, B. E.; Dairaghi, D. J.; Schall, T. J.; Collins, T. L.; Medina, J. C. Bioorg. Med. Chem. Lett. 2006, 16, 2800.

(7) L'Helgoual'ch, J. M.; Seggio, A.; Chevallier, F.; Yonehara, M.; Jeanneau, E.; Uchiyama, M.; Mongin, F. J. Org. Chem. 2008, 73, 177.

(8) García-Álvarez, P.; Mulvey, R. E.; Parkinson, J. A. Angew. Chem. Int. Ed. 2011, 50, 9668.

(9) Mosrin, M.; Knochel, P. Chem. Eur. J. 2009, 15, 1468.

(10) (a) Mongin, F.; Uchiyama, M. Curr. Org. Chem. 2011, 15, 2340. (b) Armstrong, D. R.; Kennedy, A. R.; Mulvey, R. E.; Parkinson, J. A.; Robertson, S. D. Chem. Sci. 2012, 3, 2700.

(11) Bettayeb, K.; Tirado, O. M.; Marionneau-Lambot, S.; Ferandin, Y.; Lozach, O.; Morris, J. C.; Mateo-Lozano, S.; Drueckes, P.; Schaechtele, C.; Kubbutat, M. H. G.; Liger, F.; Marquet, B.; Joseph, B.; Echalier, A.; Endicott, J. A.; Notario, V.; Meijer, L. Cancer Res. 2007, 67, 8325.

(12) 2-Chloro- $\alpha$-(2-chloro-3-pyridyl)- $\alpha$-phenyl-4-pyrimidinemethanol (4b)

$i$-PrMgCl. $\mathrm{LiCl}$ (about $1.3 \mathrm{M}$ THF solution, $1.2 \mathrm{mmol}$ ) was stirred with 2,2,6,6-tetramethylpiperidine $(0.21 \mathrm{~mL}, 1.2 \mathrm{mmol})$ at r.t. for $48 \mathrm{~h}$. The resulting solution was cooled at $-60{ }^{\circ} \mathrm{C}$ before introduction of a cooled solution of 2-chloropyrimidine (2, 0.11 g, $1.0 \mathrm{mmol})$ in THF $(2 \mathrm{~mL})$. After $2 \mathrm{~h}$ at $-40^{\circ} \mathrm{C}$, a solution of the ketone $1 \mathrm{a}(0.26 \mathrm{~g}, 1.2 \mathrm{mmol})$ in THF $(4 \mathrm{~mL})$ was added at $-60^{\circ} \mathrm{C}$. The mixture was stirred overnight at r.t. before addition of $\mathrm{H}_{2} \mathrm{O}$ $(0.5 \mathrm{~mL})$ and dilution with EtOAc $(20 \mathrm{~mL})$. The organic layer was dried over $\mathrm{MgSO}_{4}$, filtered, and concentrated under reduced pressure. Purification was performed by chromatography on silica gel (eluent: heptane-EtOAc, 7:3) to afford $\mathbf{4 b}$ in $51 \%$ yield as a yellow powder; mp $90{ }^{\circ} \mathrm{C} .{ }^{1} \mathrm{H}$ NMR $\left(300 \mathrm{MHz}, \mathrm{CDCl}_{3}\right): \delta=$ $4.97(\mathrm{~s}, 1 \mathrm{H}), 7.18$ (dd, $1 \mathrm{H}, J=7.8,4.7 \mathrm{~Hz}), 7.33(\mathrm{dd}, 1 \mathrm{H}, J=7.8$, $1.9 \mathrm{~Hz}), 7.36(\mathrm{~d}, 1 \mathrm{H}, J=5.2 \mathrm{~Hz}), 8.37$ (dd, $1 \mathrm{H}, J=4.7,1.9 \mathrm{~Hz})$, 7.35-7.45 (m, $5 \mathrm{H}), 8.60(\mathrm{~d}, 1 \mathrm{H}, J=5.2 \mathrm{~Hz}) \mathrm{ppm} .{ }^{13} \mathrm{C}$ NMR $(75$ $\left.\mathrm{MHz}, \mathrm{CDCl}_{3}\right): \delta=80.5(\mathrm{C}), 117.6(\mathrm{CH}), 122.3(\mathrm{CH}), 127.5(2 \mathrm{CH})$, $128.7(\mathrm{CH}), 128.8(2 \mathrm{CH}), 138.2(\mathrm{C}), 139.9(\mathrm{CH}), 140.7(\mathrm{C}), 149.4$ (CH), $150.8(\mathrm{C}), 160.1(\mathrm{CH}), 161.0(\mathrm{C}), 175.0$ (C) ppm. ESI-HRMS: $m / z$ calcd for $\mathrm{C}_{16} \mathrm{H}_{11}{ }^{35} \mathrm{Cl}_{2} \mathrm{~N}_{3} \mathrm{NaO}[\mathrm{M}+\mathrm{Na}]^{+}$: 354.0177; found: 354.0178 .

(13) 4-Iodo-2-(methylthio)pyrimidine (5a)

To a stirred, cooled $\left(0^{\circ} \mathrm{C}\right)$ solution of 2,2,6,6-tetramethylpiperidine $(0.50 \mathrm{~mL}, 3.0 \mathrm{mmol})$ in THF $(6 \mathrm{~mL})$ were successively added BuLi (about 1.6 M hexanes solution, $3.0 \mathrm{mmol}$ ) and, 5 min later, $\mathrm{ZnCl}_{2} \cdot \mathrm{TMEDA}^{7}(0.26 \mathrm{~g}, 1.0 \mathrm{mmol})$. The mixture was stirred for 15 min at $0{ }^{\circ} \mathrm{C}$ before introduction of 2-(methylthio)pyrimidine $(3,0.25 \mathrm{~g}, 2.0 \mathrm{mmol})$. After $2 \mathrm{~h}$ at this temperature, a solution of $\mathrm{I}_{2}(0.76 \mathrm{~g}, 3.0 \mathrm{mmol})$ in THF $(10 \mathrm{~mL})$ was added. The mixture was stirred overnight before addition of an aqueous saturated 
solution of $\mathrm{Na}_{2} \mathrm{~S}_{2} \mathrm{O}_{3}(10 \mathrm{~mL})$ and extraction with EtOAc $(3 \times 20$ $\mathrm{mL}$ ). The combined organic layers were dried over $\mathrm{MgSO}_{4}$, filtered, and concentrated under reduced pressure. Purification was performed by chromatography on silica gel (eluent: heptane-EtOAc, 95:5) to afford $\mathbf{5 a}$ in $77 \%$ yield as a beige powder; mp $52{ }^{\circ} \mathrm{C}$ (ref. 14: 52-53 ${ }^{\circ} \mathrm{C}$ ). ${ }^{1} \mathrm{H}$ NMR (300 MHz, $\left.\mathrm{CDCl}_{3}\right): \delta=2.54(\mathrm{~s}, 3 \mathrm{H}), 7.40(\mathrm{~d}, 1 \mathrm{H}, J=5.1 \mathrm{~Hz}), 8.00(\mathrm{~d}, 1 \mathrm{H}$, $J=5.1 \mathrm{~Hz}) \mathrm{ppm}$

(14) Majeed, A. J.; Antonsen, O.; Benneche, T.; Undheim, K. Tetrahedron 1989, 45, 993. 